ANNA PALUSZEK

Instytut Stosunków Międzynarodowych UMK

\title{
Muzułmanin oznacza dobry obywatel. Nowe koncepcje obecności muzułmanów w Europie
}

D la większości stałych odbiorców przekazów nie tylko medialnych, ale naukowych dotyczących współczesnych muzułmanów podobne stwierdzenie może się wydać efektem przesadnej politycznej poprawności lub przejawem ignorancji w stosunku do zagrożenia, jak „islamski terroryzm”, „fundamentalizm muzułmański” czy „święta wojna, czyli dżihad”. Jednak czy rzeczywiście można odmówić wyznawcom islamu prawa do bycia dobrym obywatelem, mieszkańcem kraju cywilizacji zachodniej?

Od lat islam najczęściej występuje w przekazach medialnych w kontekście walki i zagrożeń, jakie z sobą niesie dla świata. Taki sposób przedstawiania islamu i muzułmanów pojawia się nie tylko przy okazji opisów walk, toczących się na przestrzeni ostatnich lat na Bliskim Wschodzie, w Afganistanie, czy w Sudanie. Można zaryzykować stwierdzenie, że ten rodzaj postrzegania został przeniesiony na muzułmanów w ogóle, niezależnie od ich miejsca zamieszkania i zawodu - muzułmanin zawsze i wszędzie może być potencjalnym terrorystą. Właśnie przez pryzmat konfliktu i zagrożenia przedstawiane zaczęły być społeczności muzułmanów europejskich a raczej, sugerując się nagłówkami prasowymi, powinniśmy stwierdzić - muzułmanie zamieszkujący Europę.

Spróbujmy jednak spojrzeć na obecne na starym kontynencie społeczności muzułmańskie także z innego punktu widzenia, mianowicie z perspektywy tych organizacji, myślicieli, naukowców i działaczy, którzy starają się 
przekonać sceptyczne społeczeństwa europejskie do tego, że ich miejsce jest już w tym momencie w Europie i nie musi prowadzić do zderzenia, lecz może być spotkaniem.

Żywotność mniejszości muzułmańskich w Europie oraz definiowanie ich odrębności nie tylko przez przynależność narodową, lecz także wyznawaną religię, przyczyniły się do pojawienia się wielu głosów o zagrożeniu islamskim dla Europy oraz niemożności pogodzenia tożsamości muzułmanina i obywatela państwa demokratycznego. Dlatego też szeroko dyskutowaną kwestią jest problem kompatybilności wartości islamu oraz wartości państwa demokratycznego, szczególnie możliwość pogodzenia laickości ${ }^{1}$ ze światopoglądem muzułmanina.

Atmosferę nieufności wokół imigrantów muzułmańskich podgrzały demonstracje wyznawców islamu $\mathrm{w}$ odpowiedzi na ukazanie się w prasie europejskiej karykatur m.in. Proroka Muhammada, rozruchy na przedmieściach miast francuskich, czy zabójstwo reżysera Submission - Theo van Gogha. Wydarzenia te zwróciły uwagę, że postrzegane powszechnie za odrębne kulturowo i geograficznie cywilizacje europejska i islamska stały się poprzez rosnącą mniejszość muzułmańską bliskimi sąsiadami.

\section{Zderzenie cywilizacji czy kontakt kultur?}

Dyskusja, która toczy się w Europie, wpisuje się we wcześniejszą wymianę poglądów o nowym układzie sił po rozpadzie ZSRR i zmianie świata dwubiegunowego na jedno- bądź wielobiegunowy.

Mamy do czynienia z kontaktem kultur czy też ze zderzeniem cywilizacji? Czy dojdzie do procesu akulturacji, rozumianego jako powstanie nowej jakości, czy do konfliktu? A więc, czy obecność muzułmanów w Europie jest wyzwaniem czy zagrożeniem dla społeczeństw państw demokratycznych?

Gdy Francis Fukuyama przedstawił swoją teorię „końca historii” i z dużą dozą optymizmu ogłosił zwycięstwo liberalnej demokracji, na której kończy się ewolucja systemu politycznego oraz kapitalizmu jako systemu gospodarczego ${ }^{2}$, przyjęto jego pozytywne myślenie za oczywiste - przecież kończyła się era naznaczona półwiecznym konfliktem kolosów. Pomimo niedopełnienia się optymistycznego scenariusza „końca historii i ostatniego człowieka" autor tezy twierdzi, że jest ona nadal aktualna, choć zarzuca się

Chodzi tu o laickość o charakterze politycznym, która oznacza rozdział państwa od religii oraz jego neutralność, co objawia się m.in. zagwarantowaniem swobody wyboru wyznania obywatelowi. Zob. A. Parzymies, Muzułmanie w Europie, Warszawa 2005, s.14.

Zob. F. Fukuyama, Koniec historii, przeł. T. Bieroń, M. Wichrowski, Warszawa 1997. 
jej, że nie bierze pod uwagę takich okoliczności jak radykalizm islamski ${ }^{3}$. Według Fukuyamy pesymistyczne wizje świata po 11 września 2001r. mogą zadziałać jak samospełniająca się przepowiednia, podczas gdy globalna rzeczywistość nie jest tak tragiczna, jak powszechnie się uważa ${ }^{4}$. W pewnym sensie sytuacja na świecie zweryfikowała tezę amerykańskiego politologa, ale nie podważyła jej całkowicie, wszak pomimo kryzysów fala demokracji, cofając się w pewnych rejonach świata takich, jak Ameryka Łacińska, podnosi się w innych, czego dowodem był pewien wzrost aktywności obywatelskiej, chociażby na Ukrainie, w Kirgistanie czy w Gruzji.

Powszechnie uznaje się jednak, że Fukuyama przedwcześnie ogłosił zwycięstwo demokracji, natomiast Europa z coraz bardziej widocznymi i aktywnymi mniejszościami muzułmańskimi przez wielu ukazywana jest jako dowód na zasadność tezy Huntingtona, że odmienność cywilizacyjna doprowadzi głównie do napięć i starćs. Konflikty pomiędzy cywilizacjami wynikać będą ze zmniejszania się świata w wyniku globalizacji oraz utożsamiania się ludzi bardziej z kulturą i religią niż państwem. Trudno jednak się zgodzić z tezą, że istnieją jasno określone, jednolite kulturowo obszary cywilizacyjne, a współczesne tarcia toczą się na ich granicach. Harold Müller, profesor Uniwersytetu im J. W. Goethego, zwraca również uwagę na niewiadome pochodzenie przedstawianych przez Huntingtona danych dotyczących ilości konfliktów międzycywilizacyjnych, które mają stanowić 50\% wszystkich sporów. H. Müller, opierając się na statystykach Heidelberskiego Instytutu Badań nad Konfliktami stwierdza, że spośród 27 odnotowanych w 1996 roku wojen i krwawych konfliktów, które prowadziły ludzi do utraty życia, tylko 9 mogłoby opierać się o „cywilizacyjne linie pęknięcia”.

Uproszczona wizja świata przedstawiona przez Huntingtona znalazła zrozumienie i poparcie u współczesnego przeciętnego odbiorcy. Zapewne wbrew intencjom autora tezy, stała się ona głównym argumentem dla przeciwników integracji i możliwości współistnienia w wielokulturowej Europie muzułmanów i Europejczyków. Według podejścia „zderzeniowego”, nawiązującego nazwą do teorii Huntingtona, nie byłoby szans na pokojowe istnienie w społeczeństwach zachodnich muzułmanów jako zbiorowości odmien-

R. Scruton, Islam, Europa, Fukuyama i koniec historii, przeł. T. Bieroń, „Europa”, nr 126, 2006, s. 6.

F. Fukuyama, To nie koniec świata. Nadmierny pesymizm nie popłaca, przeł. T. Bieroń, „Europa”, Nr 150, 2007, s. 5 .

Zob. S. P. Huntington, Zderzenie cywilizacji i kształtowanie nowego ładu światowego, przeł. H. Jankowska, Warszawa 2000.

P. Marczewski, Świat nauki i mediów wobec tezy „zderzenia cywilizacji” Samuela Huntingtona, w: Zderzenie cywilizacji: sąd nad teoria Samuela Huntingtona, P. Marczewski, P. Świeżak (red.), Warszawa 2006, s. 23. 
nych kulturowo i religijnie. Tymczasem pomimo spektakularnych niejednokrotnie trudności, jakie stwarzają różnice kulturowe, po obu stronach znajdujemy osoby i grupy mówiące i dowodzące, że Europa wcale nie musi być miejscem zderzenia, lecz raczej spotkania obu kultur.

Stary kontynent jawi się obecnie jako obszar ich zetknięcia. Z jednej strony fakt ten nie pozwala na zamknięcie się na cywilizację islamską, która stała się poprzez obecność imigrantów elementem krajobrazu europejskiego i daje to nadzieje na spełnienie się optymistycznej wizji autorstwa Fukuyamy, że to demokracja będzie triumfować. $Z$ drugiej strony Europa jest ostrzegana, że na jej terenie dojdzie do mniej lub bardziej pokojowej próby ekspansji w postaci osiedlających się muzułmanów, którzy ją zislamizują, jeśli ta ich nie wchłonie i nie zintegruje.

\section{Koncepcje rozwoju obecności muzułmanów w Europie}

Badacze społeczności europejskich muzułmanów zwracają uwagę na ogromną niejednorodność poszczególnych grup, szczególnie ze względu na kraj pochodzenia. Należy podkreślić również, że pewne zachowania, które Europejczycy uznają za wynikające z islamu, są często przekazywane z pokolenia na pokolenie wraz z tradycjami z kraju pochodzenia imigrantów. Stosunek do Europy wynika także z genezy emigracji, w zależności od tego, czy była to emigracja zarobkowa, czy ucieczka przed prześladowaniem. Ważnym czynnikiem jest również stosunek pomiędzy państwem pobytu a imigrantem - czy był on mieszkańcem byłej kolonii, tak jak w przypadku Francji czy Wielkiej Brytanii, czy przyjazd wynikał z podpisywanych umów, jak w przypadku Turków w Niemczech.

Pomimo wielu czynników i różnych dróg życiowych imigrantów, pojawiają się próby ich podziału według kryterium reprezentowanego przez nich stosunku do Europy. Anna Parzymies wyróżnia wśród muzułmanów w Europie dwie podstawowe grupy. Pierwsza dąży do zintegrowania, druga odbiera integrację jako zdradę religii i korzeni, a na obce normy społeczne reaguje samoizolacją lub agresją ${ }^{7}$.

Bardziej szczegółowo, da się wyróżnić cztery postawy muzułmanów w stosunku do Europy ${ }^{8}$. Z jednej strony można uznać, że w wyniku dyskryminacji muzułmanin może poszukiwać tożsamości poprzez powrót do ko-

A. Parzymies, Wstęp, w: A. Parzymies, dz. cyt., s. 17.

Por. A. Skowron-Nalborczyk, Islam w Europie - historia i wspótczesność, w: Od krucjat do spotkania w duchu św. Franciszka z Asyżu, S. B. Brzuszek, A. Skowron-Nalborczyk (red.) Warszawa-Rzym 2005, s. 171-190. 
rzeni (często kultury i religii kraju przodków) oraz odrzucenie i negację kultury zastanej. Taki stan objawia się zazwyczaj zamykaniem się w gettach i separacją od reszty społeczeństwa. Jednocześnie ta grupa jest najbardziej podatna na wpływ tzw. misjonarzy w wyniku swojego sfrustrowania. Natomiast „misjonarze” traktują Europę jak tradycyjny dar al-harb (obszar wojny); miejsce do pełnienia misji nawracania na drogę islamu. Mimo że grupa ta jest niewielka, to właśnie ich działania, ze względu na ich spektakularność, przedstawiane są jako reprezentatywne dla muzułmanów. Trzecią postawę reprezentują muzułmanie, dążący do połączenia wyznawanej religii z europejskimi zasadami demokracji poprzez integrację. Ta część społeczności muzułmańskiej stara się przez aktywną współpracę z władzami państw pobytu, organizację konferencji, stowarzyszeń, federacji, wyjść naprzeciw wymogom europejskich demokracji, ponieważ uznaje Europę za swój dom. Spotkać się można także z przypadkami przyjęcia wartości europejskich i odrzuceniem bądź negacją własnych, a więc z asymilacjąa

\section{Asymilacja}

Asymilacja, rozumiana jako „roztopienie się mniejszości etnicznej czy rasowej w grupie większościowej i tym samym uzyskanie pełnej partycypacji w jej szansach życiowych"10 pojawia się w wypowiedziach muzułmanów jako zagrożenie dla ich tożsamości. Jest to naturalne w sytuacji, gdy grupa mniejszościowa różni się w dużym stopniu od społeczeństwa, w którym żyje. Obcość religijna, rasowa, kulturowa często powoduje całkowite odrzucenie asymilacyjnych aspiracji, a wręcz prowokuje do wzmożonej solidaryzacji z członkami tej samej mniejszości, co w efekcie prowadzi do izolacji.

Właściwie postawa asymilacyjna możliwa jest w pojedynczych przypadkach, ponieważ wymaga odrzucenia wszelkich ideałów oraz tradycji wyniesionych $\mathrm{z}$ domu na rzecz wartości zastanych w kraju pobytu ${ }^{11}$. Zjawisko takie mogłoby spotkać się z oporem nie tylko ze strony muzułmanina, który rezygnuje ze swych korzeni, lecz także ze strony społeczności lokalnej. $\mathrm{Z}$ drugiej strony można podać przykład muzułmanów zamieszkujących Europę od stuleci, np. rodzimi Tatarzy czy Pomacy i Albańczycy na Bałkanach, jako doskonały przykład zasymilowania ze społecznością lokalną. Obecnie jednak proces napływu muzułmanów do Europy jest tak nasilony, że naturalne zdolności adaptacyjne społeczeństw nie wystarczają i procesy

Podział na trzy grupy muzułmanów w Europie uznaje się za najlepiej oddający rzeczywistość. Por. R. J. Pauly, Islam In Europe. Integration or marginalization?, Burlington 2004, s. $146-154$.

10 P. Sztompka, Socjologia, Warszawa 2004, s. 352.

11 A. Skowron-Nalborczyk, Europa z chustą na głowie, „Więź”, nr 3, 2003, s. 13. 
asymilacyjne zachodzące w efekcie długoletniej obecności i kontaktu praktycznie nie występują.

Całkowita asymilacja muzułmanów w zachodnich społeczeństwach według arabisty M. M. Dziekana nie jest możliwa. Bardzo często czują się oni członkami wspólnoty, w skład której wchodzi rodzina, także ta dalsza spoza Europy, z którą utrzymywane są zazwyczaj silne więzi ${ }^{12}$. Jednakże ze strony konserwatystów pojawiają się głosy ostrzeżenia. Szczególnie aktywni w tej kwestii Daniel Pipes oraz Bernard Lewis ${ }^{13}$ twierdzą, że jeśli nie dojdzie do „asymilacji, z pewnością dojdzie do konfliktów” ${ }^{14}$ i napięć. Jest to postawa reprezentowana przez grupy widzące relacje z muzułmanami przez pryzmat historii zatargów, jakie miały miejsce w przeszłości, a ich obecność na Zachodzie interpretujące jako ekspansję i chęć opanowania nowych obszarów.

Polityka asymilacji wprowadzana przez państwa europejskie polegała głównie na niezauważaniu obecności rosnącej grupy muzułmańskiej, przy wymogu samodzielnego dostosowywania się muzułmanów do warunków europejskich bez wsparcia ze strony państwa. Jednocześnie miało miejsce torpedowanie wszelkich prób zinstytucjonalizowania obecności wyznawców islamu, jak budowa meczetów i nauczanie religii w szkole, co zakończyło się na przykładzie Francji rozruchami ulicznymi na przedmieściach, wydaleniem uczennic za noszenie hidżabów, wreszcie wprowadzeniem ustawowego zakazu noszenia ostentacyjnych symboli religijnych ${ }^{15}$. Dużym utrudnieniem we wprowadzaniu jednoznacznej polityki wobec muzułmańskich mniejszości w takich państwach, jak Francja, Wielka Brytania, Niemcy, Portugalia, Hiszpania, Szwecja, Włochy, jest brak oficjalnego uznania islamu przez państwo, co zaprzecza w pewnym sensie deklaracjom chęci realizacji idei integracji w tych państwach ${ }^{16}$.

12 M. M. Dziekan, Małe szanse na współpracę muzułmańskich wspólnot z władzami z 22.07.2005, dostępne: http://www2.arabia.pl/content/view/280132/2/, [20.03.2006].

13 Autor analizujący relacje i kontakty Świat Islamu - Świat Zachodu, w sposób jednoznacznie dyskredytujący współczesnych muzułmanów, uznany przez E. Saida za jednego z twórców współczesnego, negatywnego obrazu cywilizacji muzułmańskiej; Zob. B. Lewis, Co sie właściwie stało? O kontaktach Zachodu ze światem islamu, przeł. J. Kozłowska, Warszawa 2003.

14 A. Praski, Islam w Europie - bać się czy nie?, „Myśl Polska”, nr 9, 2005, dostępne: http://www.myslpolska.icenter.pl/index.php?menu=swiat\&nr=20050227101812 [30.04.2006].

15 P. Semka, Między chustą a krzyżem, dostępne: http://www.tertio.krakow.pl/strony/teksty/ Debaty/debata36/d_36_10_txt.htm [27.04.2007].

16 A. Skowron - Nalborczyk, Status prawny mniejszości muzułmańskich w wybranych państwach europejskich, „Sprawy Narodowościowe”, z. 22, 2003, s. 143-144. 


\section{Integracja}

W ramach powyższego pojęcia mieści się wiele koncepcji. Na wstępie warto rozważyć problem podnoszony przez wielu Europejczyków, mianowicie czy możliwe jest pogodzenie islamu z panująca w krajach europejskich zasadą rozdziału władzy Boga od władzy doczesnej człowieka ${ }^{17}$. W islamie władza należy wyłącznie do Boga ${ }^{18}$, taka teza znajdzie potwierdzenie w Koranie i Sunnie. Jednak jak zwraca uwagę Anna Parzymies, tekstów religijnych nie należy w sposób dosłowny, z pominięciem historycznego i społecznego kontekstu ${ }^{19}$.

Zwolennicy tezy o możliwości pogodzenia systemów wartości zlaicyzowanego świata zachodniego z wartościami świata islamu, zorientowanego religijnie, przekonują o tworzeniu się nowej jakości; „Euro-islamu”, „islamu obywatelskiego” czy „islamu europejskiego”. Proces ten ma być efektem wspólnej pracy Europejczyków - muzułmanów i niemuzułmanów nad pogodzeniem wiary muzułmanina $\mathrm{z}$ byciem lojalnym obywatelem państwa zamieszkania. Czynnikiem sprzyjającym może stać się motywacja, uzasadnienie dla przebywania w Europie, a więc np. wolność polityczna czy wolność słowa. Dyskusja o nieprzystawalności „europejskiego” oraz „muzułmańskiego" systemu wartości często zasadza się na przekonaniu, że nie istnieją wartości ogólnoludzkie, czyli wspólne zarówno muzułmaninowi i Europejczykowi $^{20}$.

\section{Islam obywatelski - koncepcja integracji wielowymiarowej}

Koncepcja islamu obywatelskiego zasadza się na pojęciu obywatelskości posiadającej nie tylko wymiar polityczny, wyrażający się w posiadaniu czynnego i biernego prawa wyborczego. Esencją obywatelskości jest zaangażowanie się jednostek w społeczeństwie obywatelskim, które kształtuje również tożsamość człowieka ${ }^{21}$.

Propagatorami islamu obywatelskiego są szczególnie muzułmanie, bardzo często działacze organizacji muzułmańskich. Choć samo dookreślanie islamu jako europejskiego, obywatelskiego czy politycznego budzić może jak zauważa Tomasz Imran Stefaniuk - sprzeciw wierzącego, ponieważ is-

A. Parzymies, dz. cyt., s.14.

Zob. S. Kitab, Zasady muzułmańskiego systemu politycznego, w: Islam a świat, R. Bäcker, S. Kitab (red.), Torun 2004, s. 9-11.

19 A. Parzymies, dz. cyt., s. 14.

20 T. Stefaniuk, Islam, Zachód, wartości, w: Islam i obywatelskość w Europie, K. Górak-Sosnowska, K. Pędziwiatr, P. Kubicki (red.), Warszawa 2006, s. 49-50.

${ }_{21} \quad$ Zob. Islam i obywatelskość..., s. 8. 
lam jest tylko jeden, to dostrzega on potrzebę używania takiego sformułowania ze względu na społeczeństwa europejskie, obawiające się spotkań islamu

z Zachodem ${ }^{22}$. Na istnienie różnych odmian islamu w nauce europejskiej zwraca uwagę Anna Parzymies, która podkreśla różnicę pomiędzy podejściem teologicznym wierzącego muzułmanina a racjonalnym, preferowanym $\mathrm{w}$ nauce europejskiej ${ }^{23}$. W związku z tym przedstawiane idee pogodzenia islamu z europejskim systemem wartości powstają głównie w celu pokazania Europejczykom, że islam nie musi być wrogi i niebezpieczny.

Właściwie koncepcja islamu obywatelskiego opiera się na prostej zasadzie „Być dobrym muzułmaninem oznacza być dobrym obywatelem”, która wyrażona została w „Deklaracji Muzułmańskiej” przygotowanej przez Federację Organizacji Muzułmańskich w Europie. Zasada ta jest różnie rozumiana i wprowadzana w życie. Poniżej przedstawiam dwóch najbardziej znanych propagatorów integracji muzułmanów europejskich oraz ich sposób patrzenia na idee obywatelskiego zaangażowania muzułmanów.

\section{Koncepcja Euro-Islamu - Bassam Tibi ${ }^{24}$}

Wątpliwość odnośnie problemu pogodzenia światopoglądu muzułmanina $\mathrm{z}$ wartościami europejskimi rozwiewa Bassam Tibi w licznych wypowiedziach oraz artykułach, tłumacząc, że nie ma jednowymiarowej tożsamości, a z pewnością nie ma jednolitej tożsamości muzułmańskiej.

Integracja według B. Tibi ma trzy aspekty: prawny, ekonomiczny oraz kulturowy ${ }^{25}$. Prawna integracja, polegająca na czysto formalnym włączeniu muzułmanina do społeczeństwa poprzez nadanie obywatelstwa kraju pobytu, jest w pewnym sensie najprostsza i nie niesie za sobą rzeczywistego poczucia przynależności ze strony imigranta. Aspekt ekonomiczny opiera się przede wszystkim na prawie do pracy i zwraca uwagę na odpowiedzialne przyjmowanie tzw. Gastarbeiterów. B. Tibi zwraca uwagę na istotny wpływ posiadania pracy i zabezpieczenia ekonomicznego muzułmanów na ich integrację ze społeczeństwem czy występowanie izolacji.

Ostatni, najbardziej skomplikowany aspekt, czyli integracja kulturowa, wyrażająca się wyznawaniem takich samych wartości, jest niezbędnym wa-

T. Stefaniuk, Islam, Zachód..., s. 49.

A. Parzymies, dz. cyt., s. 20.

Bassam Tibi - profesor na Uniwersytecie w Getyndze; autor licznych publikacji na temat świata islamu, fundamentalizmu religijnego oraz islamu w Europie.

25 L. Włodek-Biernat, Islam po europejsku. Rozmowa z politologiem Bassamem Tibi, „Gazeta Wyborcza", 30 kwietnia 2006, dostępne http://serwisy.gazeta.pl/swiat/1,34181,3314696.html [30.06.2007]. 
runkiem do pokojowego współistnienia w ramach społeczeństwa. Na tym poziomie powstaje najwięcej wątpliwości. Kwestia pogodzenia wartości islamu z sekularyzowaną, pluralistyczną kulturą państw europejskich jest rozważana w kontekście możliwości wytworzenia nowej jakości, jaką miałby być Euro-islam.

B. Tibi podkreśla w swych wypowiedziach, że Europa powinna dbać o swoją tożsamość, na którą składają się demokracja, społeczeństwo obywatelskie, prawa człowieka. Euro-islam przeciwstawia idei islamizacji Europy poprzez dawa ${ }^{26}$ oraz koncepcji hidżry ${ }^{27}$, co - jak przyznaje sam pomysłodaw$\mathrm{ca}$ - wymaga reformy religijnej islamu na potrzebę europejskich warunków $^{28}$. Kwestia reformy sposobu interpretowania Koranu, podnoszona wcześniej przez takie autorytety jak Abdullah Ahmed an-Na'im, nie urzeczywistnia się chociażby ze względu na współpracę reformatorów z zachodnimi uczelniami oraz trudną do przełamania tradycję opierania przepisów prawa (szari'at) na bardziej restrykcyjnych zapisach Koranu, pochodzących z okresu późniejszego - medyneńskiego. Wynika to z przyjętej zasady, że objawienia późniejsze w przypadku sprzeczności usuwają wcześniejsze ${ }^{29}$.

Niemiecki uczony podkreśla jednocześnie, że przewartościowanie islamu mogłoby się odbyć jedynie w odpowiedzi na potrzeby europejskiej społeczności muzułmańskiej, która jest inkluzyjna, a islam powinien stać się jej częścią, rezygnując z misji nawracania ${ }^{30}$. W przeciwnym razie Europie grozi powstawanie enklaw muzułmańskich oraz segregacja kulturowa, a w efekcie żywotności grup muzułmańskich oraz stałego napływu imigrantów - islamizacja.

Droga do realizacji takiej koncepcji jest trudna i wymaga wysiłku wszystkich państw europejskich oraz ich współpracy z grupami proeuropejskich muzułmanów, przy jednoczesnym zwalczaniu separatystów i dzihadystów. Tibi twardo stoi na stanowisku nieodstępowania od wartości państwa laickiego, demokratycznego. Koncepcja ta nie jest przez muzułmanów rozumiana i przyjmują ją opornie, szczególnie w Niemczech, gdzie tu-

26 Dawa - koncepcja nauczania o islamie niemuzułmanów. Obowiązek dawa ciąży na każdym muzułmaninie, a polega na zapraszaniu do islamu, w pewnym sensie prozelityzm.

27 Hidżra - emigracja (na wzór Muhammada), koncepcja mówiąca o wywędrowaniu ze świata niewiernych. Radykalne nurty rozumieją ją również jako nakaz do wywędrowania ze swoich obozów by walczyć z niewiernymi, co ma swój wyraz w zamachach terrorystycznych. Cyt. za: J. Danecki, Podstawowe wiadomości o islamie, t. 2, Warszawa 2002, s. 146.

28 B. Tibi, Euro-islam jako europejski most między cywilizacjami. Europeizacja islamu, w: Islam i obywatelskość..., s. 15.

29 R. Bäcker, Islam: między fundamentalizmem a totalitaryzmem, w: Islam a świat..., s. 88.

30 B. Tibi, Euro-islam..., s. 19. 
recka mniejszość tworzy enklawy, a jej członkowie czasem nie starają się być Niemcami, preferując miano „Turka z paszportem niemieckim”.

Wielu ocenia koncepcję Tibiego jako pobożne życzenie uczonego, którego argumenty nie zawsze docierają do przeciętnego europejskiego muzułmanina. Ma on natomiast coraz większy posłuch wśród rządzących, których niezdecydowana polityka i brak wsparcia dla integracji doprowadziły właśnie do separacji.

\section{Pobożna obywatelskość — Tariq Ramadan}

Postać Tariqa Ramadana wzbudza wiele kontrowersji - z jednej strony przedstawiany jest jako propagator europejskiego islamu, nawołującego muzułmanów do integracji w ramach społeczeństw europejskich, z drugiej oskarżany o głoszenie idei wojującego islamu, dążącego do islamizacji Europy. Bassam Tibi odżegnuje się od jakiegokolwiek związku ideologicznego $\mathrm{z}$ wnukiem Hasana al-Bany (twórcy Stowarzyszenia Braci Muzułmanów), określając go mianem islamisty ${ }^{31}$. Oskarżenia o związek z Al-Kaidą oraz wspieranie terroryzmu pojawiły się m.in. przy odmowie pozwolenia na wjazd do Stanów Zjednoczonych. Pomimo kontrowersji jakie wzbudza, często ukazywany jest jako przywódca duchowy młodych Europejczyków. Ramadan proponuje muzułmanom mieszkającym $\mathrm{w}$ państwach europejskich koncepcję „pobożnej obywatelskości” ${ }^{2}$, polegającą na jednoczesnym uczestnictwie w życiu społecznym i politycznym oraz byciu pobożnym muzułmaninem. Ma ona stanowić kompromis pomiędzy francuską polityką asymilacji wymagającą od obywateli prywatyzacji religii a angielską polityką wielokulturowości prowadzącą do społecznej gettoizacji muzułmanów ${ }^{33}$. Genewski uczony twierdzi, że jest możliwe pogodzenie dwóch tożsamości - religijnej i obywatelskiej, jako przykład przedstawia siebie samego i własną drogę dochodzenia do odkrycia swej tożsamości.

W przeciwieństwie do Bassama Tibi, Ramadan nie uważa, że religia jest kwestią osobistą muzułmanina oraz że powinien zarzucać obowiązek dawa, aby nie być postrzeganym jako „misjonarz”. W swej hutbie z 1997 roku naucza, że każdy muzułmanin powinien pamiętać o swoim obowiązku dawa szczególnie na Zachodzie, gdzie wielu ludzi zapomniało, czym jest Bóg i wia-

B. Tibi, Euro-islam..., s.15.

32 K. Pędziwiatr, Być blisko Boga walcząc o swoje prawa - wywiad z Tarikiem Ramadanem, w: Islam $i$ obywatelskość..., s. 11-12.

33 K. Pędziwiatr, Tajemnica popularności Tarika Ramadana, dostępne: http://www.psz.pl/ content/view/3318 [30.04.2007]. 
$\mathrm{ra}^{34}$. Podstawowym działaniem muzułmanina powinno być szerzenie wiedzy o „drodze islamu”, aby dać możliwość wyboru społeczeństwu, w którym żyje, a nade wszystko powinien dawać dobry przykład wiary i praktyki. Jednocześnie wyjaśnia, że islam nie jest kulturą, lecz systemem zasad i uniwersalnych wartości i sami muzułmanie nie mogą go mylić z tradycjami kraju pochodzenia czy kraju przodków ${ }^{35}$. Powinni natomiast skupić się na islamie, który pozwala wiernym adaptować pewne aspekty charakterystyczne np. dla kultury brytyjskiej czy francuskiej. Historia islamu dała wiele przykładów na przyswojenie przez islam lokalnych zwyczajów i tradycji, często różniących się od siebie.

Za podstawowe problemy społeczności muzułmańskich w Europie Ramadan uznaje skłonność do separacji oraz niechęć do włączania się w życie codzienne społeczeństw europejskich. Dostrzega również symptomy kryzysu tożsamości, szczególnie wśród młodych muzułmanów, którzy są rozdarci pomiędzy chęcią uczestniczenia $\mathrm{w}$ życiu swych rówieśników, a wartościami nauczanymi $\mathrm{w}$ domu rodzinnym. $\mathrm{W}$ swoich wystąpieniach wspomina także o „mentalności ofiary” charakterystycznej dla wielu muzułmanów oraz o mówieniu na temat dyskryminacji, przy braku podejmowania działań w kierunku jej zwalczania. Ramadan naucza, że muzułmanie powinni większą uwagę zwrócić na siebie, na swoją postawę i zmienić swoje nastawienie do Europy jako wspólnego domu. Przeciwstawia się postawie propagowanej przez ekstremistów, mówiących: „Jesteś muzułmaninem, gdy jesteś przeciwko Zachodowi" ${ }^{36}$.

Tarik Ramadan mówi o „cichej rewolucji”, jaka odbywa się w Europie, i ma nadzieję, że konkluzje, do jakich dojdą muzułmanie w państwach europejskich, pokażą drogę rozwoju ich współwyznawcom z krajów tradycyjnie islamskich. Do istotnych kwestii należy m.in. oddanie kobietom należnych im praw niezależnych jednostek, które nadaje im islam, a z powodu obciążonej kulturowo interpretacji nadal funkcjonuje przyzwolenie na dyskryminację kobiet na rynku pracy, przymusowe małżeństwa oraz przemoc domową ${ }^{37}$.

Tarik Ramadan dociera ze swym przesłaniem do tych, którzy mają problem z tożsamością europejskiego muzułmanina. Jednocześnie daje Europejczykom nadzieję na to, że nawet gorliwie praktykujący muzułmanie

${ }_{34}$ T. Ramadan, Da'wa in the West, dostępne: http://www.tariqramadan.com/imprimer. php3?id_article=72, [19.03.2007].

35 T. Ramadan, British identity: an open and plural identity, „The Guardian” z 21.01.2005, dostępne http://www.tariqramadan.com/imprimer.php3?id_article=204, [19.03.2007].

36 T. Ramadan, Islam in Europe, dostępne: http://www.tariqramadan.com/imprimer. php3?id_article=73, [19.03.2006].

37 K. Pędziwiatr, Być blisko..., s. 13. 
nie muszą stać się zagrożeniem dla społeczeństwa czy pożywką dla ekstremistów. Mimo to, pobożność oraz wypełnianie da'wa stwarzać może poczucie zagrożenia dla zlaicyzowanych społeczeństw, jak francuskie, czy też grup religijnych, np. chrześcijańskich, zauważających w nauczaniu Ramadana wiele elementów misyjnych.

\section{Walczący islam (dżahidyści) — islamizacja Europy?}

Przed islamizacją Europy ostrzegała w bardzo jednoznacznym tonie włoska publicystka Oriana Fallaci, która krytykowała przede wszystkim poprawność polityczną dyskusji na ten temat. Sama tej poprawności unikała, określając islam jako jednoznaczne zagrożenie dla judeo-chrześcijańskiej Europy. Z takim postawieniem sprawy nie zgadzają się arabiści i islamolodzy, którzy zwracają uwagę na wielowiekowe współistnienie islamu i społeczeństw chrześcijańskich (Agata Skowron-Nalborczyk). Jednocześnie podkreślają dwustronność relacji, co implikuje wpływ postawy Europejczyków wobec islamu i muzułmanów na odbiór Zachodu przez tych ostatnich (M. M. Dziekan). Zwraca się uwagę na zagubienie samych Europejczyków w postmodernistycznej rzeczywistości, a obawy przed islamem w tym kontekście odbierane są jako dowód na lęk przed utratą tradycyjnej już dominacji. Nie zaprzeczają istnieniu tendencji fundamentalistycznych, a czasem ekstremistycznych wśród imigrantów, jednak podkreślają potrzebę oddzielenia „działań grupki szaleńców” od obecności obywateli wyznania muzułmańskiego (Marcin Styszyński) ${ }^{38}$.

Imigranci przybywający do Europy korzystają z wolności słowa oraz wszelkich swobód państwa demokratycznego i część muzułmanów mieszkających na Zachodzie może się zgodzić chociażby z tymi słowami Abu al-Ala al-Maududiego: „W pełni otwarcie powiadam wam muzułmanom, że sekularystyczna demokracja pod każdym względem stoi w sprzeczności z waszą religią i wiarą (...) Tam gdzie dominuje polityczny system demokracji i świeckiego państwa narodowego, nie ma miejsca dla islamu. Tam gdzie włada islam, takiego systemu nie może być" ${ }^{39}$.

Nie jest to środowisko jednorodne. $Z$ jednej strony zaliczyć można tu osoby, utożsamiające się z poglądami szejków saudyjskich, określane mianem szejkistów. Wiąże się to $\mathrm{z}$ możliwościami zaciągania porad prawnych (fatw) przez Internet u uczonych muzułmańskich, co pokazuje jasno, że zamknięcie granic nie odetnie zamieszkujących Europę muzułmanów od

38 Powyższe wypowiedzi zostały zawarte w Ankiecie Teofila. Zob. „Teofil. Pismo kolegium filozoficzno-teologicznego Dominikanów", nr 2 (24), 2006, s. 47-53.

39 Abu al-Ala al-Maududi, Al-islam wa al-madanija al-hadisa, Kair 1980, s. 41-42, cyt. za: B. Tibi, Fundamentalizm religijny, Warszawa 1997, s.33. 
wpływu często radykalnych uczonych. Na ulicach europejskich miast można zauważyć skutki stosowania się do zaleceń uczonych saudyjskich, interpretujących islam według oficjalnej doktryny Arabii Saudyjskiej — wahhabizmu.

Natomiast część muzułmanów o poglądach radykalnych może uważać szejków saudyjskich za uzurpatorów - są to zazwyczaj muzułmanie pozostający pod wpływem Braci Muzułmanów ${ }^{40}$. Stowarzyszenie Braci Muzułmanów traktuje Europę jak dar al-islam, czyli terytorium muzułmańskie (pomimo dotychczasowej przewagi chrześcijan), które zmieni się z czasem na korzyść islamu w wyniku imigracji i dużej rozrodczości imigrantów.

Jednak nie każda fundamentalistycznie nastawiona grupa, którą cechuje poczucie misji nawrócenia bądź zniszczenia świata zachodniego, chce realizować swe plany poprzez przemoc. Przykładem może być partia Hizb ut-Tahrir, której program zakłada osiągnięcie zwycięstwa islamu na świecie i powstanie kalifatu przy użyciu metod pokojowych, takich jak ulotki, odczyty, bezpośrednia propaganda czy aktywność w określonych środowiskach. Innym popularnym nurtem w Europie był swego czasu rygorystyczny ruch tabligh (szerzenie wiary islamu), który wymagał od muzułmanów, zamieszkujących kraje europejskie życia według zasad z czasów Muhammada, łącznie ze strojem, sposobem spania, czy jedzenia. Ruch wywodził się z Pakistanu, lecz z czasem wpływy tablighów zaczęły maleć ze względu na trudność zastosowania się do zasad ${ }^{41}$.

\section{Islam zagrożeniem dla demokracji?}

W efekcie zamachów terrorystycznych powstały uproszczenia myślowe - każdy muzułmanin jest fundamentalistą, a następnie terrorystą, a islam jest religią, która w mniej lub bardziej zawoalowany sposób nawołuje do dżihadu (sic!). Samo pojęcie dżihadu zdobyło niesłychaną popularność, często stając się głównym określnikiem islamu. Tymczasem pojęcie to było i jest interpretowane $\mathrm{w}$ dużym stopniu w zależności od przynależności do szkoły prawnej czy sytuacji geopolitycznej. W Koranie wymienione są dwa rodzaje walki: obrona przed nieprzyjacielem albo zwalczanie przeciwników, a więc obronna albo agresywna. W tej drugiej formie staje się ona synonimem kital (bezpośredniej walki) ${ }^{42}$.

Współcześnie dżihad jest wykorzystywany w celach propagandowych zarówno przez państwa muzułmańskie, jak i niektóre grupy muzułmanów. Obejmuje znaczeniowo kital, czyli walkę na zewnątrz, ale jest to zarazem

\footnotetext{
A. Parzymies, dz. cyt., s. 17.

${ }^{41} \quad$ Tamże, s. 18.

${ }_{42}$ J. Danecki, Kłopoty z dzihadem, w: Islam a terroryzm, A. Parzymies (red.), Warszawa 2003, s. 47.
} 
wezwanie do walki z własnymi słabościami, aby być dobrym muzułmaninem. Walkę tę określa się mianem wielkiego dżihadu i muzułmanin może go prowadzić indywidualnie ${ }^{43}$.

Za największe niebezpieczeństwo zarówno dla muzułmanów, jak i niemuzułmanów można uznać radykalizm w postaci fundamentalizmu religijnego, często kojarzonego wyłącznie z islamem, pomimo że jest charakterystyczny dla większości religii. Bassam Tibi podkreśla, żeby nie nie mylić islamu z fundamentalizmem. Przypomina, że fundamentalizm religijny jest ideologią polityczną odwołującą się do islamu ${ }^{44}$. Piotr Kłodkowski stawia natomiast tezę, że fundamentalizm wyrasta z samego „serca” islamu i rzeczywiście odzwierciedla jego ideowe przesłanie, zastrzegając, że fundamentalizm nie jest jednoznaczny z terroryzmem, choć praktyka niektórych muzułmanów temu zaprzecza ${ }^{45}$. Mimo że fundamentalizm nie jest domeną wyłącznie islamu, o czym przypomina Selim Chazbijewicz, z dużą lekkością łączymy te dwa pojęcia, tworząc bardzo powszechne uproszczenia myślowe, nawet podczas naukowych dywagacji ${ }^{46}$.

Wrażenie wyobcowania czy też czucie się obywatelem drugiej kategorii zazwyczaj stanowi idealną pożywkę dla wszelkich radykalizmów. Przy frustracjach muzułmańskich imigrantów - mieszkańców przedmieść, młodych ludzi, którzy pomimo zdobytego wykształcenia mają trudności ze zdobyciem pracy, włączeniem się do życia społecznego czy politycznego z powodu chociażby obco brzmiącego nazwiska ${ }^{47}$ wytłumaczalna staje się popularność imamów, którzy za głoszenie radykalnych poglądów byli wydalani ze swoich krajów, natomiast uzyskiwali azyl w państwach Europy Zachodniej. Oczywiście nie do wytłumaczenia jest przemoc w imię odwetu, lecz z pewnością próby zrozumienia motywacji grup konfliktowych pozwoli na znalezienie wspólnych poziomów komunikacji.

\section{Segregacja i gettoizacja społeczności przyczyną radykalizmu}

Młodzi ludzie rozbici pomiędzy konserwatywnym domem a przesiąkniętym wolnością zachodnim stylem życia są często dobrym „materiałem”, dla grup ekstremistycznych, ponieważ dają one łatwe rozwiązania na to, co wydaje się przesądzone $\mathrm{w}$ wyniku stygmatyzacji społecznej. Dlatego też

43 R. Bäcker, Islam: między fundamentalizmem..., s. 90.

44 Zob. B. Tibi, Fundamentalizm religijny..., s. 71.

45 P. Kłodkowski, Wojna światów? O iluzji wartości uniwersalnych, Kraków 2002, s. 46-47.

46 S. Chazbijewicz, Muzułmanie nie maja monopolu na fuindamentalizm. Ankieta Teofila, w: „Teofil. Pismo kolegium filozoficzno-teologicznego Dominikanów", nr 2 (24), 2006, s. 45

47 M. M. Dziekan, dz. cyt. 
Tarik Ramadan w wielu swoich wystąpieniach wzywa młodych muzułmanów do przeskoczenia bariery swojego pochodzenia. Muzułmanie często sami zamykają się w gettach. Z jednej strony jest to naturalne, ponieważ łatwiej o zbudowanie infrastruktury religijnej, gdy w jednej dzielnicy mieszkają głównie rodziny muzułmańskie. $\mathrm{Z}$ drugiej strony jest to wynik zgody społecznej na tworzenie się takich enklaw, co pozwala na unikanie problemu, jakim jest integracja, a więc działanie obu stron.

Konrad Pędziwiatr w wyniku badań przeprowadzonych wśród rodzin pakistańskich w Wielkiej Brytanii doszedł do wniosku, że w wyniku tworzenia enklaw pakistańskich islam jest nieustannie $w$ "zasięgu ich ręki" ${ }^{48}$. Izolacji od świata zewnętrznego, także innych muzułmanów sprzyja tradycja aranżacji małżeństw oraz silne związki z krajem, co w efekcie daje coraz silniej odczuwaną odrębność kulturową i religijną.

Radykalizm pozostaje nadal widmem, które dręczy Europę, lecz zwraca to wreszcie uwagę na istnienie grup, które mają problem z dostosowaniem się do norm europejskich. Jednocześnie aktywizują się grupy muzułmanów, którzy czują się obywatelami państw europejskich. Może to zaowocować oddolnym, jak i odgórnym procesem znajdowania sposobów i miejsc spotkań kultur życia, aby nie dochodziło do nieustannych zderzeń.

\section{Podsumowanie}

Z pewnością dyskusje na temat relacji islamu z Zachodem zeszły z poziomu teoretycznych dywagacji politologów, tworzących kompleksowe teorie, jak huntingtonowskie „zderzenia cywilizacji” czy „koniec historii” Fukuyamy. W ostatnich latach intensywnie włączyli się w nie praktycy, a co najważniejsze - muzułmanie, których głosów nie sposób ignorować.

Poprzez pojawienie się drugiego i trzeciego pokolenia dawnych imigrantów w pewnym stopniu dokonała się swoista integracja, jak to określa Bassam Tibi - polityczna i ekonomiczna (choć nie zawsze), ale problemem czy też kwestią dyskusyjną pozostaje integracja tożsamościowa, świadoma i zideologizowana. $Z$ pewnością tak bliskie sąsiedztwo będzie powodem wielu starć oraz zderzeń, ale też - równolegle - powolnej, lecz konsekwentnej wymiany, przenikania się dwóch kultur życia. Dzieje się tak niezależnie od teoretycznych założeń naukowców, działaczy czy publicystów, których generalizacje bądź nadmierne skupianie się na przypadkach szczególnych, nijak mają się niejednokrotnie do decyzji podejmowanych przez przeciętnego europejskiego muzułmanina. Według konfliktowych teorii społecznych

48 Zob. K. Pędziwiatr, Instytucjonalna baza w Wielkiej Brytanii a tożsamość religijna brytyjskich Pakistańczyków, „Studia Socjologiczne”, nr 1, 2002. 
starcia są nieuniknione i wszechobecne w rozwoju społeczeństw. To brak zakłóceń zewnętrznych i wewnętrznych doprowadzić może do sztywności struktur i niezdolności przyswajania innowacji ${ }^{49}$. Ważne jest odpowiednie monitorowanie konfliktów społecznych, aby nie narastały i nie przybierały na intensywności, działanie na rzecz rozwoju, lecz nie przeciwko systemowi. Przełomem wydaje się podejmowanie przez muzułmanów typowo demokratycznych metod działania, tj. zakładanie organizacji, stowarzyszeń, współpraca $z$ instytucjami państwowymi. Problemem pozostaje częste przenoszenie podziałów etnicznych, narodowych z krajów pobytu, co znacznie utrudnia komunikację pomiędzy samymi muzułmanami, a w efekcie powoduje trudności na płaszczyźnie kontaktów z władzami.

Podsumowując, sytuacja obecna wskazuje na prawdopodobieństwo dalszych działań grup radykalistów, tudzież tradycjonalistów, lecz przy wzmacniającym się głosie tych, dla których Europa stała się domem. Przy odpowiednim wsparciu ze strony państw, skupiających się w równym stopniu na integracji i problemach swoich społeczności muzułmańskich, jak na zwalczaniu międzynarodowego terroryzmu, możliwy jest stopniowy proces integracji.

A N N A P A L U S Z E K

${ }_{49}$ M. Budyta-Budzyńska, Mniejszości narodowe - bogactwo czy problem?, Warszawa 2003, s. 200. 


\section{Muslim means a good citizen. New conceptions of Muslims' existence in Europe}

The article of Anna Paluszek considers the issue of rising number of Muslim citizens in European countries and their place in democratic society.

The aim of the paper is to present different ways of perceiving Muslims in Europe. The author poses two essential questions: does Islam and Europe together mean a clash or a meeting and a dialogue? Does being a Muslim exclude being a citizen in western democracy?

Nowadays, Muslims are one of the most popular minorities in Europe attracting an attention of the media. Unfortunately, the majority of the information about Islam and Muslims which can be found in the media refers to terrorists' attacks, fundamentalism, djihad and conflicts. In this context a rising number of Muslims in Europe is presented as a danger for democracy and for the European way of thinking. The author wants to show the diversity of Islamic groups in Europe and tries to give some examples of positive ways of thinking about Muslims in Europe.

While analysing theories and conceptions about relationship between Islamic and western civilisations, various ways of the future coexistence (assimilation, integration or marginalisation) of Muslims in European countries are presented.

Another significant aspect was a presentation of a possibility of Muslims' integration in Europe as the most expected perspective, but the hardest to imagine. The representatives of this trend in discussion about Islam in Europe are Tariq Ramadan and Bassam Tibi. Both of them try to convince European societies and European Muslims that they can exist together and that they can be a part of the same democratic society. Contrary to assimilation or marginalization, integration needs effort from governments, Muslim and European society and from the individuals.

The article leads to the conclusion that there is more than one possible way of coexistence of Islamic religion and western way of thinking. The alternative may be considered as harder and more demanding, but it seems to be the only way of any further progress. 